\title{
KELUARGA DAPAT MEMOTIVASI MAHASISWA KEPERAWATAN BERHENTI MEROKOK
}

\author{
${ }^{1}$ Yanyan Bahtiar \\ ${ }^{1}$ Dosen Poltekkes Kemenkes Tasikmalaya \\ Email:comebing@gmail.com
}

\begin{abstract}
Abstrak
Penelitian ini bertujuan untuk mengetahui hubungan karakteristik; usia, pendidikan, riwayat merokok dengan tingkat motivasi. Metode penelitian menggunakan metode deskriptif dengan pendekatan crosssectional. Sampel penelitian adalah sampel populasi, berjumlah 50 responden. Instrument penelitian menggunakan kuesioner yang sebelumnya dilakukan uji instrument. Hasil analisa menggambarkan bahwa sebagian besar responden berada pada tingkat III Prodi D3 Keperawatan sebanyak 33 orang $(66 \%)$, lebih dari setengah responden berada pada kelompok usia $\geq 21$ tahun, sebagian besar responden memiliki riwayat keluarga merokok sebanyak 30 orang (60\%) dan motivasi responden paling banyak berada pada tingkat sedang yaitu 25 orang $(50 \%)$. Hasil analisa bivariat menunjukan bahwa berdasarkan uji statistik fisher's exact antara tingkat pendidikan dengan motivasi tidak ada hubungan yang signifikan ( $\rho$-value $=0,077$ ). Hasil uji chi-square antara kelompok usia dengan motivasi menunjukkan tidak ada hubungan yang signifikan ( $\rho$-value $=$ 0,090). Sedangkan hasil uji statistik fisher's exact antara riwayat merokok dengan motivasi berhenti merokok menunjukkan ada hubungan yang signifikan $(\rho$-value $=0,001)$. Keinginan atau motivasi seseorang dalam merubah perilaku merokok dipengaruhi oleh berbagai faktor, diantaranya; faktor internal yang melekat dalam dirinya sendiri, dan faktor eksternal terutama lingkungan keluarga. Penelitian ini diharapkan dapat menjadi data dasar penelitian selanjutnya yang melahirkan intervensi keperawatan untuk berhenti merokok.
\end{abstract}

Kata Kunci : Motivasi, perilaku merokok, riwayat keluarga, pendidikan keperawatan, usia.

\begin{abstract}
This study aims to determine the relationship of characteristics; age, education, smoking history to the level of motivation. The research method using descriptive method with cross sectional approach. The research sample is a sample of the population, account for 50 respondents. Instrument research using questionnaires previously tested the instrument. The results of the analysis shows that most respondents are at level III Nursing Prodi D3 33 persons (66\%), more than half of the respondents were in the age group $\geq 21$ years, the majority of respondents had a family history of smoking as many as 30 people (60\%) and motivation most respondents were at a moderate level that is 25 people (50\%). The results of the bivariate analysis showed that based on the statistical test offisher's exact between level of education and motivation there was no significant relationship ( $\rho$-value $=0.077$ ). Chi-square test results between the age group with the motivation showed no significant relationship ( $\rho$-value $=0.090)$. While the results of statistical fisher's exact test between smoking history and motivation to quit smoking showed the significant correlation ( $\rho$-value $=0.001)$. A person's desire or motivation in changing smoking behavior is influenced by various factors, including; Internal factors inherent in itself, and external factors, especially the family environment. This study is expected to be a data base that gave birth to the next research nursing interventions for smoking cessation.
\end{abstract}

Keywords: Motivation, smoking, family history, nursing education, age.

\section{PENDAHULUAN}

Rokok merupakan salah satu fenomena yang mengancam derajat kesehatan Indonesia. Lebih dari 60 juta penduduk Indonesia adalah perokok aktif. Jumlah ini

terus bertambah dari tahun ke tahun dan menempatkan Indonesia ke peringkat ketiga dengan jumlah perokok aktif tertinggi di dunia. Sebanyak 62 juta perempuan dan 30 juta laki- 
laki Indonesia menjadi perokok pasif, sedangkan pada kelompok anak-anak usia 0-4 tahun ada 11,4 juta yang terpapar asap rokok (Kemenkes, 2013).

Terdapat beberapa faktor menjadi pemicu kelompok remaja berperilaku merokok, seperti faktor orang tua, faktor teman, faktor stress dan iklan. Masifnya iklan, promosi dan sponsor rokok menjadi pemicu naiknya jumlah perokok baru, terutama remaja dan anak. Remaja yang terpapar iklan rokok mempunyai kemungkinan dua kali lipat lebih besar untuk menjadi perokok (Dimyati, 2011).

Tingginya prevalensi merokok tidak sebanding dengan ketersediaan pelayanan untuk berhenti merokok. Menurut WHO, (2012) dalam 12 bulan terakhirdi Indonesia hampir $50 \%$ dari perokok berpikir tentang berhenti merokok dan lebih dari 30\% dari mereka membuat upaya untuk berhenti merokok. Hasil survei Lembaga Menanggulangi Masalah Merokok (LM3) sekitar 70-80 persen perokok ingin berhenti merokok, tapi hanya 3 persen yang berhasil. Kegagalan berhenti merokok ini dipengaruhi oleh beberapa faktor; 42,9\% tidak tahu caranya, $25,7 \%$ sulit berkonsentrasi dan 2,9\% terikat oleh sponsor rokok. Sementara itu yang berhasil berhenti merokok; kesadaran sendiri $76 \%$, karena sakit $16 \%$, dan karena tuntutan profesi $8 \%$ (Ulfa, 2009). Keinginan atau motivasi seseorang dalam merubah perilakunya dipengaruhi oleh berbagai faktor, diantaranya; faktor internal yang melekat dalam diri sendiri, dan faktor eksternal yang didominasi lingkungan terdekatnya.

Hasil survey peneliti pada bulan Pebruari 2016 terhadap mahasiswa Poltekkes Tasikmalaya; mahasiswa perokok paling banyak adalah Jurusan D3 Keperawatan Tasikmalaya dibandingkan 5 jurusan lainnya yaitu berjumlah 50 orang. Sedangkan berdasarkan wawancara pada 6 orang mahasiswa, 5 orang mengatakan bahwa keinginan untuk berhenti merokok (motivasi) kadang-kadang ada karena sekarang menjadi mahasiswa kesehatan, tapi sering hilang dengan keinginan yang kuat untuk merokok. Empat dari enam orang siswa mengatakan di keluarganya juga ada yang merokok. Berdasarkan fenomena tersebut peneliti melakukan penelitian mengenai hubungan karakteristik dengan tingkat motivasi berhenti merokok pada Mahasiswa D3 Keperawatan Tasikmalaya Poltekkes Tasikmalaya.

\section{METODEPENELITIAN}

Rancangan penelitian menggunakan metode deskriptif korelasi dengan pendekatan potong lintang (crosssectional). Teknik sampling yang digunakan adalah total sampling dengan jumlah sampel yaitu sampel populasi yang memenuhi kriteria penelitian. Kriteria inklusi penelitian diantaranya adalah mahasiswa Prodi D3 Keperawatan Tasikmalaya, saat pengumpulan data masih berperilaku merokok, bersedia menjadi responden penelitian.

Jumlah sampel yang terlibat dalam penelitian ini adalah 50 responden. Instrument yang digunakan adalah kuesioner untuk mengukur tingkat motivasi mahasiswa dalam berhenti merokok dan angket untuk mengidentifikasi karakteristik responden. Kuesioner dilakukan uji instrument pada 20 orang mahasiswa keperawatan STIKes BTH Tasikmalaya.

Analisa penelitian yang dilakukan adalah analisa univariat dan bivariat.Analisa univariat untuk menggambarkan distribusi frekuensi dari variable-variabel yang diteliti.Sedangkan analisa bivariat menggunakan uji Chi-Squere dan fisher's exact testuntuk mengetahui hubungan diantara variabel indevenden (karakteristik mahasiswa) dan variabel devenden (motivasi mahasiswa).

\section{HASIL PENELITIAN}

\section{Analisa Univariat}

Karakteristik mahasiswa Prodi D3 Keperawatan Tasikmalaya Poltekkes Kemenkes Tasikmalaya dapat dilihat pada table 1. Sebagian besar responden berdasarkan tingkat pendidikan berada pada tingkat III D3 Keperawatan sebanyak 33 orang $(66 \%)$. Berdasarkan kelompok usialebih dari setengah responden berada pada kelompok usia Usia $\geq 21$ tahun. Dan berdasarkan riwayat merokok keluarga sebagian besar 
responden memiliki keluarga dengan perilaku merokok sebanyak 30 orang (60\%).

Tabel 1. Distribusi frekuensi karakteristik Mahasiswa

\begin{tabular}{lccc}
\hline Karakteristik & Katagori & Frekuensi & Persentasi \\
\hline Tingkat & Tingkat I & 8 & $16 \%$ \\
\cline { 2 - 4 } Pendidikan & Tingkat II & 9 & $18 \%$ \\
\cline { 2 - 4 } & Tingkat III & 33 & $66 \%$ \\
\hline $\begin{array}{l}\text { Kelompok } \\
\text { Usia (tahun) }\end{array}$ & Usia 18-20 & 22 & $44 \%$ \\
\cline { 2 - 4 } $\begin{array}{l}\text { Riwayat } \\
\text { Keluarga }\end{array}$ & Ada & 28 & $56 \%$ \\
\cline { 2 - 4 } & Tidak ada & 20 & $60 \%$ \\
\hline \multicolumn{2}{c}{ Jumlah } & 50 & $100 \%$ \\
\hline \multicolumn{2}{c}{} & &
\end{tabular}

Distribusi frekuensi motivasi mahasiswa dalam berhenti merokok dapat dilihat pada table 2. Tingkat motivasi responden yang paling banyak berada pada tingkat sedang berjumlah 25 orang (50\%).Sedangkan yang paling sedikit berada pada tingkat motivasi tinggi berjumlah 12 orang (24\%).

Tabel 2. Distribusi frekuensi motivasi mahasiswa

\begin{tabular}{ccc}
\hline Tingkat Motivasi & Frekuensi & Persentasi \\
\hline Rendah & 13 & $26 \%$ \\
\hline Sedang & 25 & $50 \%$ \\
\hline Tinggi & 12 & $24 \%$ \\
\hline Jumlah & 50 & $100 \%$ \\
\hline
\end{tabular}

\section{Analisa Bivariat}

Tabel 3. Hubungan tingkat pendidikan perawat dengan motivasi berhenti merokok.

\begin{tabular}{cccc}
\hline Tingkat & \multicolumn{2}{c}{ Tingkat Motivasi } & \multirow{2}{*}{ Jumlah } \\
\cline { 2 - 3 } Pendidikan & R+Sedang & Tinggi & \\
\hline Tingkat I+II & 10 & 7 & 17 \\
\hline Tingkat III & 28 & 5 & 33 \\
\hline Jumlah & 38 & 12 & 50 \\
\hline
\end{tabular}

Hasil analisis hubungan antara tingkat pendidikan perawat dengan motivasi berhenti merokok diperoleh data bahwa ada 7 orang responden tingkat I dan II memiliki motivasi tinggi dalam berhenti merokok, dan ada 28 orang responden tingkat III memiliki motivasi rendah sedang. Berdasarkan hasil uji statistik fisher's exact test menunjukkan tidak ada hubungan yang signifikan antara tingkat pendidikan perawat dengan motivasi berhenti merokok ( $\rho$ value $=0,077$ )

Tabel 4. Hubungan kelompok usia dengan motivasi berhenti merokok

\begin{tabular}{ccccc}
\hline Kelompok & \multicolumn{3}{c}{ Tingkat Motivasi } & \multirow{2}{*}{ Jumlah } \\
\cline { 2 - 4 } Usia (tahun) & Rendah & Sedang & Tinggi & \\
\hline Usia 18-20 & 3 & 11 & 8 & 22 \\
\hline Usia $\geq 21$ & 10 & 14 & 4 & 28 \\
\hline Jumlah & 13 & 25 & 12 & 50 \\
\hline
\end{tabular}

Hasil analisis hubungan antara kelompok usia dengan motivasi berhenti merokok diperoleh data bahwa ada 8 orang responden kelompok usia 18-20 tahun memiliki motivasi tinggi dalam berhenti merokok, dan ada 14 orang responden usia $\geq 21$ tahun memiliki motivasi sedang. Berdasarkan hasil uji chisquare menunjukkan tidak ada hubungan yang signifikan antara kelompok usia dengan motivasi berhenti merokok ( $\rho$ value $=0,090$ ).

Tabel 5. Hubungan riwayat merokok keluarga dengan motivasi berhenti merokok

\begin{tabular}{lccc}
\hline \multirow{2}{*}{$\begin{array}{l}\text { Riwayat } \\
\text { Merokok }\end{array}$} & \multicolumn{2}{c}{ Tingkat Motivasi } & \multirow{2}{*}{ Jumlah } \\
\cline { 2 - 3 } & R+Sedang & Tinggi & \\
\hline Ada & 28 & 2 & 30 \\
\hline Tidak Ada & 10 & 10 & 20 \\
\hline Jumlah & 38 & 12 & 50 \\
\hline
\end{tabular}

Hasil analisis hubungan antara riwayat merokok keluarga dengan motivasi berhenti merokok diperoleh data bahwa ada 10 orang responden yang tidak ada riwayat merokok pada keluarganya memiliki motivasi tinggi dalam berhenti merokok, dan ada 28 orang responden yang ada riwayat merokok pada keluarganya memiliki motivasi rendah sedang. Berdasarkan hasil uji statistik fisher's exact test menunjukkan ada hubungan yang signifikan antarariwayat merokok dengan motivasi berhenti merokok ( $\rho$ value $=0,001$ )

\section{PEMBAHASAN}

Mahasiswa adalah seseorang yang sedang dalam proses menimba ilmu ataupun belajar dan terdaftar sedang menjalani pendidikan pada salah satu bentuk perguruan 
tinggi yang terdiri dari akademik, politeknik,sekolah tinggi, institut dan universitas (Hartaji, 2012). Menurut Siswoyo dan Dwi, (2007) mahasiswa disebut sebagai individu yang sedang menuntut ilmu ditingkat perguruan tinggi, baik negeri maupun swasta atau lembaga lain yang setingkat dengan perguruan tinggi. Perguruan tinggi dapat menjadi masa penemuan intelektual dan pertumbuhan kepribadian bagi setiap mahasiswa.

Seorang mahasiswa dikategorikan pada tahap perkembangan usia 18 sampai 25 tahun. Tahap ini dapat digolongkan pada masa remaja akhir sampai masa dewasa awal. Bila dilihat dari tahap dan tugas perkembangan pada usia ini merupakan pemantapan pendirian hidup (Hurlock, 2002). Mahasiswa dinilai memiliki tingkat intelektualitas yang tinggi, kecerdasan dalam berpikir dan kerencanaan dalam bertindak. Berpikir kritis, bertindak cepat dan tepat merupakan sifat yang cenderung melekat pada diri seorang mahasiswa. Tetapi fenomena yang terjadi di dunia kampus malah sebaliknya, termasuk kampus kesehatan dengan banyak mahasiswa yang berperilaku merokok. Perilaku merokok sering dipersepsikan sebagai penemuan jati diri dan eksistensi diri.

Pada penelitian ini menggambarkan bahwa paling banyak dari mahasiswa keperawatan yang berperilaku merokok adalah tingkat III atau tingkat akhir di program diploma III yaitu 60\%nya. Sejalan dengan penelitian Musdalifah dan Setijadi (2011), yang mengungkapkan dalam penelitiannya bahwa latar belakang pendidikan tidak berpengaruh secara signifikan terhadap perilaku merokok. Sedangkan menurut Dimyati, (2011) konsumsi rokok di kalangan mahasiwa Indonesia cenderung meningkat setiap tahunnya. Terjadi kenaikan secara signifikan rata-rata frekuensi merokok di kalangan mahasiswa pada tahun 2009, yakni $24,5 \%$ mahasiswa dan 2,3\% mahasiswi. Begitu juga pada penelitian ini, bertambahnya usia $(\rho$-value $=0,077)$ dan bertambahnya tingginya tingkat pendidikan dari mahasiswa keperawatan $(\rho$-value $=0,090)$ tidak berpengaruh terhadap keinginan mahasiswa untuk berhenti merokok.

Perilaku merokok juga bisa dipengaruhi oleh lingkungan sosial dan keluarga, terutama orang tua. Hasil penelitian Prof Hasbullah menggambarkan bahwa dari 1000 responden sebanyak $44,5 \%$ responden mengakui memiliki keluarga yang merokok dan umumnya anggota keluarga laki-laki. Sebanyak 96,8\% mengetahui bahaya merokok dan sebanyak $60 \%$ yang merokok mengaku sulit berhenti dari perilaku merokok (Michico, 2016). Orang tua terkadang tidak menyadari bahwa setiap kepulan asap yang dihembuskan dari sebatang rokok yang dihisapnya tidak luput dari perhatian anak (Bahtiar, Badriah, dan Hidayat, 2015). Lingkungan keluarga bisa menjadi pendorong atau bisa juga menjadi penghambat perubahan perilaku anggotanya kearah perilaku sehat, termasuk dalam perilaku berhenti merokok.

Keluarga dapat memberikan motivasi pada anggotanya dalam perubahan perilaku, termasuk motivasi berhenti merokok. Seperti pada penelitian ini terdapat hubungan yang bermakna antara riwayat merokok pada keluarga mahasiswa dengan motivasi berhenti merokok mahasiswa ( $\rho$-value= 0,001). Sehingga keluarga bisa memberikan motivasi sosial pada anggotanya. Notoatmojo (2010) mengungkapkan bahwa motif sosial merupakan suatu dorongan untuk bertindak yang tidak kita pelajari, namun kita pelajari dalam kelompok sosial dimana kita hidup. Motif sosial ini umumnya kompleks dan menyangkut pada keadaan umum yang mempengaruhi munculnya berbagai perilaku. Kebutuhan sosial ini adalah kebutuhan yang tidak akan terpuaskan, karena jika sudah tercapai tujuannya maka kebutuhan itu akan mengarahkan perilaku kita pada tujuan yang lain lagi.

Berbagai upaya terus dilakukan untuk dapat menekan laju pertumbuhan perokok di Indonesia yang semakin tinggi. Fenomena issue menaikkan harga rokok mungkin dapat menjadi salah satu motivasi dalam berhenti merokok, terutama di kalangan mahasiswa. Sudaryatmo dalam Anugrah (2016), 
menyatakan bahwa disatu sisi harga rokok dinaikkan, dan disisi lain pemerintah menyediakan alternatif bagi masyarakat yang mau berhenti merokok berupa terapi gratis di klinik kesehatan walaupun jumlahnya sangat terbatas. Mungkin saja kenaikan harga rokok itu tidakakan berdampak besar pada para perokok yang sudah ketagihan. Namun, semuanya berharap langkah itu dapat menekan angka pertumbuhan perokok pemula

Motivasi adalah alasan yang mendasari dari sebuah perbuatan yang dilakukan oleh seseorang. Termasuk motivasi pada seorang perokok dalam usahanya untuk berhenti merokok meruapakan suatu dorongan dari dalam diri individu sendiri, baik berasal dari nilai-nilainya sendiri ataupun dipengaruhi dari lingkungannya sehingga menimbulkan, mengarahkan dan mengorganisasikan tingkah lakukanya untuk segera berhenti merokok (Pradana 2008). Motivasi kesehatan merupakan inti dari keberhasilan seorang perokok yang mencoba untuk berhenti merokok (Winurini, 2011). Pada dasarnya seorang perokok berhasil atau tidaknya untuk berhenti merokok adalah tergantung pada keseimbangan antara motivasinya untuk berhenti merokok dan tingkat ketergantungannya terhadap rokok.

Tingkah laku seseorang dipengaruhi serta di rangsang oleh keinginan, kebutuhan, tujuan dan kepuasaan. Rangsangan timbul dari diri sendiri (internal) dan dari luar (eksternal) atau lingkungan. Rangsangan materil dan non materil ini akan menciptakan motivasi yang mendorong orang bekerja atau beraktifitas untuk memperolah kebutuhan dan kepuasan dari kerjanya (Hasibuan, 2008).

\section{DAFTAR PUSTAKA}

Anugarah, P., (2016). Apakah kenaikan harga rokok solusi efektif ?. Diunduh pada tanggal 25 oktober 2016 dari http://www.bbc.com

Bahtiar Y., Badriah, S., Hidayat, A.A.S., (2015). Hubungan riwayat merokok dalam keluarga dengan perilaku merokok mahasiswa poltekkes tasikmalaya.
Tasikmalaya: Buletin Media Informasi Poltekkes Kemenkes Tasikmalaya.

Dimyati, V., (2011). Perokok aktif terus meningkat. Diunduh pada tanggal 26 Agustus 2016 dari http://www.nasional.jurnas.com

Hasibuan, M. (2008). Organisasi dan motivasi. Jakarta: PT Bumi Aksara.

Hartaji, dan Damar, A., (2012). Motivasi berprestasi pada mahasiswa yang berkuliah dengan jurusan pilihan orangtua. Fakultas psikologi universitas gunadarma. Diunduh pada tanggal 25 pebruarai $2016 \quad$ dari http://digilib.uinsby.ac.id

Hurlock, E.B, (2002) Psikologi perkembangan. Jakarta: Erlangga

Kemenkes RI. (2013). Melindungi generasi bangsa dari iklan, promosi dan sponsor rokok, Menkes luncurkan peraturan pencantuman peringatan dan informasi kesehatan pada kemasan rokok. Diunduh pada tanggal 20 januari 2016 dari http://www.depkes.go.id

Michico, N.R., (2016). Hasil lengkap penelitian prof. Hasbullah soal harga rokok rp. 50 ribu. Diunduh pada tanggal 25 oktober 2016 dari http://news.detik.com

Musdalifah dan Setijadi, A.R., (2011). Pengaruh latar belakang pendidikan, stres, orang tua, teman, dan iklan terhadap perilaku merokok pada mahasiswa Universitas Sebelas Maret surakarta. J Respir Indo Vol. 31, no. 4, Oktober 2011.

Notoatmodjo, S., (2010). Promosi kesehatan dan ilmu perilaku. Jakarta: PT Rineka Cipta

Pradana, K.A., (2008). Dinamika motivasi mengakhiri perilaku merokok padamantan perokok yang pernah mengalami fase relapse. Jakarta: skripsi S-1 Fakultas Psikologi, Universitas Indonesia

Siswoyo, dan Dwi, (2007). IImu pendidikan. Yogyakarta: UNY Press.

Ulfa, (2009). Kenapa susah sekali berhenti merokok diunduh pada tanggal 25 juli 2016 dari http://health.detik.com 
WHO, (2012). Guidelines for controlling and monitoring the tobacco epidemic.

Winurini, S., (2011). Penyebab relapse (kembali merokok) pada perokok berat di tinjaudari health belief model. Pusat Pengkajian Pengolahan Data dan Informasi Sekretaris Jenderal DPR RI. 